\title{
Deforestation in the Kayabi Indigenous Territory: Simulating and Predicting Land Use and Land Cover Change in the Brazilian Amazon
}

\author{
Hugo de Alba Martínez*
}

Recibido el 06 de febrero de 2016; aceptado el 24 de febrero de 2017

\section{Resumen}

Las prácticas de cambio en la cobertura y uso de suelo como la cría de ganado, tala de árboles, agricultura, minería y urbanización son los mayores contribuyentes de la deforestación en el Amazonas, generando gran impacto tanto en los ecosistemas como en los procesos ambientales a diversas escalas, tales como la fragmentación y degradación del suelo, pérdida de biodiversidad y alteración en la composición atmosférica y cambio climático.

Utilizando SIG, teledetección y el Land Change Modeler de IDRISI se simuló el paisaje futuro del territorio indígena Kayabi en el Amazonas brasileño. El modelo fue capaz de simular exitosamente la expansión de la deforestación en la región así como el identificar los principales atributos del paisaje que facilitan la expansión de perturbaciones antropogénicas.

Palabras clave: Amazonas brasileño, SIG, deforestación, cambio de uso y cobertura del suelo, sensores remotos, predicción, tierra indígena, Kayabi.

\section{Resumo}

As práticas de mudanças na cobertura e uso do solo como a criação de gado, corte de árvores, agricultura, mineração e urbanização são os maiores fatores do desmatamento na Amazônia, gerando grande impacto tanto nos ecossistemas como nos processos ambientais nas diversas escalas, tais como a fragmentação e degradação do solo, perda de biodiversidade, alteração na composição atmosférica e mudança climática.

* Instituto Tecnológico y de Estudios Superiores de Occidente, Periférico Sur Manuel Gómez Morín 8585, C.P. 45604, Tlaquepaque, Jalisco, México, correo electrónico: hdealba@iteso.mx 
Utilizando-se Sistema de Informação Geográfica (SIG), sensoriamento remoto e o 'Land Change Modeler' da IDRISI se simulou a paisagem futura do território indígena Kayabi na Amazônia Brasileira. O modelo foi capaz de simular com êxito a expansão do desmatamento na região assim como identificar os principais atributos da paisagem que facilitam a expansão de perturbações antropogênicas.

Palavras chave: Amazônia brasileira, SIG, desmatamento, mudança de uso e cobertura do solo, sensores remotos, predição, terra indígena, Kayabi.

\begin{abstract}
Land use/cover change practices in the Brazilian Amazon, such as cattle ranching, logging, agriculture, mining, and urbanization are the major contributors to deforestation and have major impacts on ecosystems and environmental processes at local, regional and global scales. A simulation of future landscape in the Kayabi Indigenous Territory in the Brazilian Amazon was carried out using Geographic Information Systems (GIS), Remote Sensing and the IDRISI's Land Change Modeler. The model was able to successfully simulate deforestation expansion in the region and identify the main landscape attributes driving anthropogenic disturbance expansion in the studied area. Distance from roads and distance from existing disturbance were found as the key factors driving deforestation in the Kayabi area.

Key words: Brazilian Amazon, GIS, LUCC, deforestation, remote sensing, prediction, Indigenous Land, Kayabi.
\end{abstract}

\title{
Introduction
}

During 2007, over $80 \%$ of both current clearing and cumulative clearing has been concentrated in a band along the eastern and southern edges of the forest, this band is called the 'arc of deforestation' (Fearnside, 2007), see Figure 1. However, in addition to the overall deforestation expansion, smaller clearings that are located far from existing frontier, play a more importance role in the process than their area would suggest. These new areas serve as seeds for a more intense clearing activity in the future.

According to Asner et al., 2004 (Asner, Keller, Pereira, Zweede and Silva, 2004), the process of Land use/cover change (LUCC) is bringing a fast deforestation processes; the most common LUCC practices in the Brazilian Amazon include cattle ranching, logging, agriculture, mining, and urbanization.

LUCC practices have significant impacts that affect ecosystems and environmental processes at local, regional and global scales. Such effects include land fragmentation and degradation, biodiversity loss, alteration in atmospheric composition and climate change (Vitousek et al., 1997). 


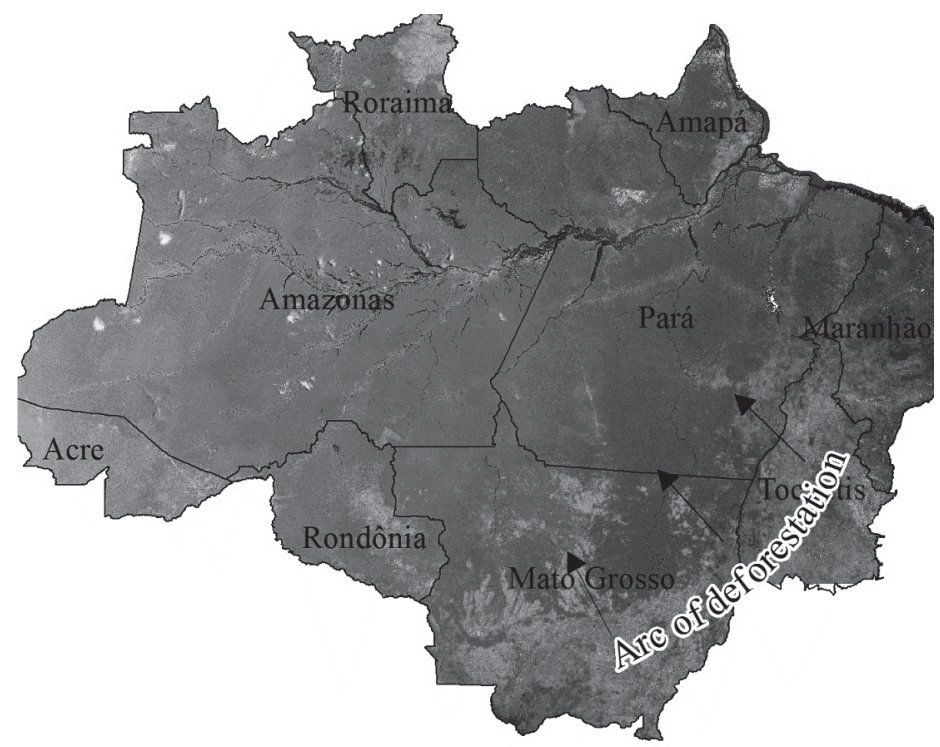

Figure 1. Arc of deforestation' in Legal Amazon.

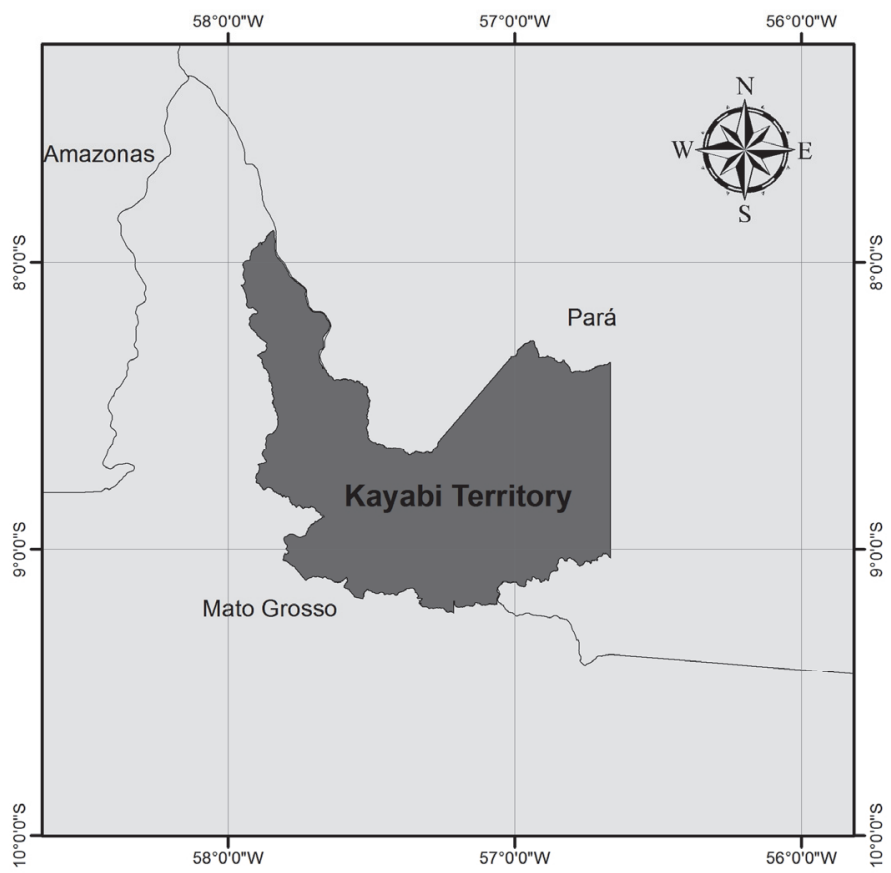

Figure 2. Location of Kayabi Territory. 
Indigenous lands and different categories of parks and reserves located at the edge of the 'arc of deforestation' serve as a primary defence against deforestation. This is the case of the Kayabi Indigenous Territory located in the states of Mato Grosso and Para, in the Brazilian Amazon. However, since 2000 anthropogenic processes have critically speeded deforestation in the Kayabi Territory. This paper aims to understand the determinants of LUCC by using a modelling approach.

In order to develop sustainable environmental management policies and adequate land use planning in the Kayabi Territory, it is vital to understand the determinants of LUCC. In this context, modelling provides insight into the land use change dynamics and its driving factors (Ademola and Takashi, 2007). In addition, models not only help to improve the understanding of these changes, but also allow us to quantitatively predict where future change might happen. For these reasons models are a very important tool to monitor and ultimately protect the forest from further deforestation.

This paper aims to investigate the deforestation process through modelling and predicting future land change for the Kayabi Indigenous Territory.

\section{Modelling LUCC in the Kayabi Indigenous Territory}

A model can be defined as a simplified representation of a phenomenon or a system (Chang, 2010). LUCC models are used to study and predict the future states of land use patterns taking into account various biophysical and socio-economic factors. Laurance et al. (2002) have assessed the effects of biophysical and anthropogenic predictors on deforestation at the Brazilian Amazon. According to their research, three types of mayor potential predictors were identified: human demographic factors (rural-population density, urban-population size), factors that affect physical accessibility to forests (linear distances to the nearest paved highway, unpaved road and navigable river) and factors that may affect land use suitability for human occupation and agriculture (annual rainfall, dry season severity, soil fertility, soil water logging, soil depth).

Future landscape prediction was developed using different GIS and IDRISI's Land Change Modeler and followed five sequential steps, presented as follows.

i. Creation of forest land cover maps from 2000, 2006 and 2009 derived from remotely sensed data;

ii. Land-change cover analysis by cross-tabulating forest land cover maps;

ii. Calculation of transition potentials from forest to anthropogenic disturbance using a MLP neural network methodology;

iv. Assessment of the model performance by predicting a 2009 land cover and comparing it with an actual 2009 land cover map; and

v. Predicting a 2020 land cover.

Each of these steps will be presented as follow. 


\section{Creation of land cover maps derived from remotely sensed data}

CLASlite software was utilized to create cover maps for each image shown in Table 1 , followed by a supervised classification using ENVI software to create 2 class land cover maps for the years 2000, 2006 and 2009 (forest and anthropogenic disturbance). The result of the classification was a 2 class map: Forest and Anthropogenic Disturbance for each of the analyzed years (see Figure 3).

The land change analysis was based on two multi-temporal land cover maps derived from a 2000 Landsat ETM+, a 2006 Landsat TM, a third land cover map, for the purpose validation of the model, was derived from two 2009 SPOT 5 images (see details in Table 1).
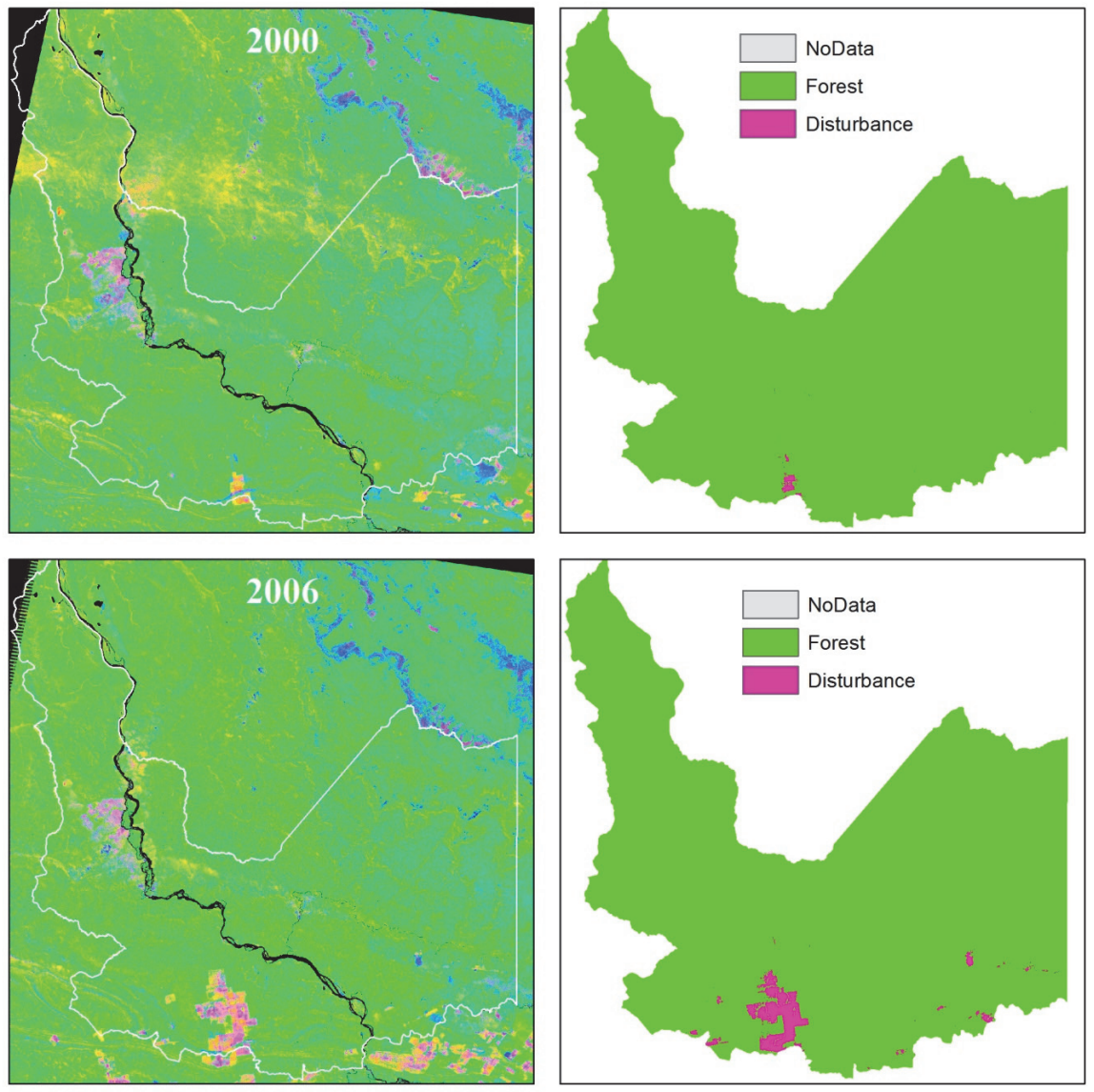

Figure 3. Resulting classification of CLASlite's fractional cover maps. 


\section{Table 1}

Characteristics of used satellite data

\begin{tabular}{|c|c|c|c|c|c|}
\hline Sensor & $\begin{array}{l}\text { Spectral } \\
\text { Bands }\end{array}$ & $\begin{array}{l}\text { Spectral } \\
\text { resolution }\end{array}$ & $\begin{array}{c}\text { Ground } \\
\text { pixel Size }\end{array}$ & $\begin{array}{l}\text { Acquisition } \\
\text { date }\end{array}$ & $\begin{array}{l}\text { Scene } \\
\text { ID }\end{array}$ \\
\hline \multirow{8}{*}{$\begin{array}{l}\text { Landsat } \\
\text { ETM+ }\end{array}$} & B1: Blue & $0.45-0.515 \mu \mathrm{m}$ & $30 \mathrm{~m}$ & $31 / 05 / 2000$ & Path/Row: 245/66 \\
\hline & B2: Green & $\begin{array}{c}0.525-0.605 \\
\mu \mathrm{m}\end{array}$ & $30 \mathrm{~m}$ & & \\
\hline & B3: Red & $0.63-0.69 \mu \mathrm{m}$ & $30 \mathrm{~m}$ & & \\
\hline & $\begin{array}{l}\text { B4: Near- } \\
\text { infrared }\end{array}$ & $0.75-0.90 \mu \mathrm{m}$ & $30 \mathrm{~m}$ & & \\
\hline & B5: SWIR & $1.55-1.75 \mu \mathrm{m}$ & $30 \mathrm{~m}$ & & \\
\hline & $\begin{array}{l}\text { B6: Ther- } \\
\text { mal-infrared }\end{array}$ & $10.4-12.5 \mu \mathrm{m}$ & $60 \mathrm{~m}$ & & \\
\hline & $\begin{array}{l}\text { B7: Mid- } \\
\text { Infrared }\end{array}$ & $2.09-2.35 \mu \mathrm{m}$ & $30 \mathrm{~m}$ & & \\
\hline & $\begin{array}{l}\text { P: Panchro- } \\
\text { matic }\end{array}$ & $0.52-0.9 \mu \mathrm{m}$ & $15 \mathrm{~m}$ & & \\
\hline \multirow{7}{*}{$\begin{array}{l}\text { Landsat } \\
\text { TM }\end{array}$} & B1: Blue & $0.45-0.52 \mu \mathrm{m}$ & $30 \mathrm{~m}$ & $25 / 06 / 2006$ & Path/Row: 245/66 \\
\hline & B2: Green & $0.52-0.6 \mu \mathrm{m}$ & $30 \mathrm{~m}$ & & \\
\hline & B3: Red & $0.63-0.69 \mu \mathrm{m}$ & $30 \mathrm{~m}$ & & \\
\hline & $\begin{array}{l}\text { B4: Near- } \\
\text { infrared }\end{array}$ & $0.76-0.9 \mu \mathrm{m}$ & $30 \mathrm{~m}$ & & \\
\hline & B5: SWIR & $1.55-1.75 \mu \mathrm{m}$ & $30 \mathrm{~m}$ & & \\
\hline & $\begin{array}{l}\text { B6: Ther- } \\
\text { mal-infrared }\end{array}$ & $10.4-12.5 \mu \mathrm{m}$ & $120 \mathrm{~m}$ & & \\
\hline & $\begin{array}{l}\text { B7: Mid- } \\
\text { Infrared }\end{array}$ & $2.08-2.35 \mu \mathrm{m}$ & $30 \mathrm{~m}$ & & \\
\hline \multirow[t]{4}{*}{ SPOT 5} & B1: Blue & $0.50-0.59 \mu \mathrm{m}$ & $10 \mathrm{~m}$ & $29 / 05 / 2009$ & $\begin{array}{c}5682369090529142034 \\
2 \mathrm{U}\end{array}$ \\
\hline & B2: Green & $0.61-0.68 \mu \mathrm{m}$ & $10 \mathrm{~m}$ & $12 / 09 / 2009$ & $\begin{array}{c}5694363090812133852 \\
2 U\end{array}$ \\
\hline & $\begin{array}{l}\text { B3: Near- } \\
\text { infrared }\end{array}$ & $0.78-0.89 \mu \mathrm{m}$ & $10 \mathrm{~m}$ & & \\
\hline & B4: SWIR & $1.58-1.75 \mu \mathrm{m}$ & $10 \mathrm{~m}$ & & \\
\hline
\end{tabular}




\section{Land Change Cover Analysis by cross-tabulating forest land cover maps}

Change from forest class to disturbance between 2000 and 2006 was assessed by using Change Analysis Tab in LCM. LCM analyses each pixel in the earlier land cover map for a transition to a different class in the later land cover image. Since there are only two land cover classes, there are four possible outcomes for each pixel (see Figure 4):

Case 1. Forest with no change (Forest persistence)

Case 2. Forest transition to Disturbance (Forest-Disturbance)

Case 3. Vegetation Re-growth (Disturbance-Forest)

Case 4. Disturbed area with no change. (Disturbance persistence)

A 3rd order polynomial trend surface was created using LCM to aid interpretation. Spatial trend analysis is an effective way of visualizing the general trend of change based on the observed change between two land cover maps and, as can be seen in Figure 5, makes evident change from forest to disturbance is concentrated in the south part of the image which is consistent with the deforestation tendency observed on the 'arc of deforestation'.

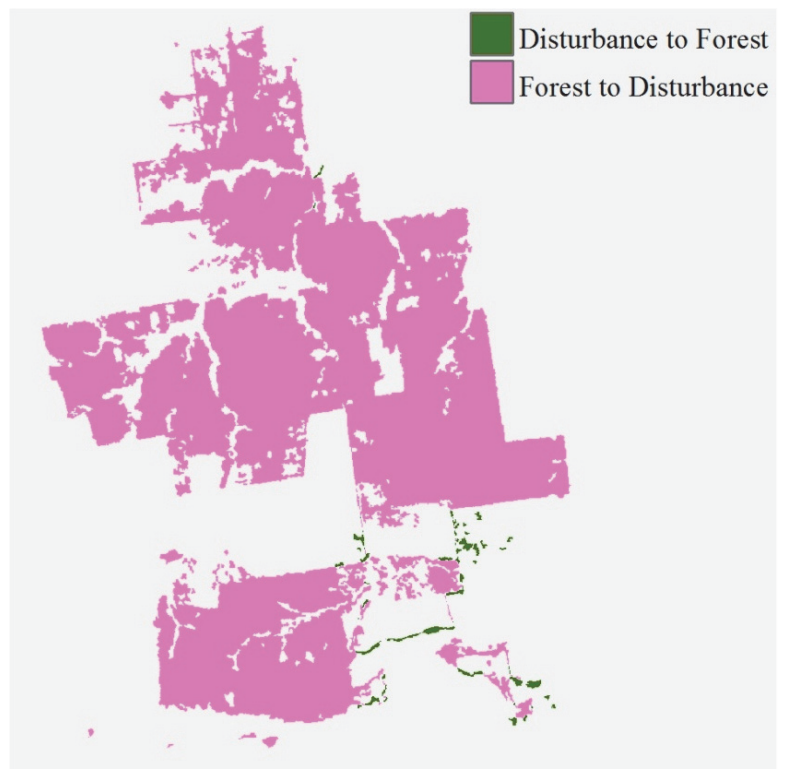

Figure 4. Class transitions calculated by LCM. ${ }^{1}$

1 Transitions less than 500 hectares were ignored in the model as they are likely to be a map error in image co registration. 


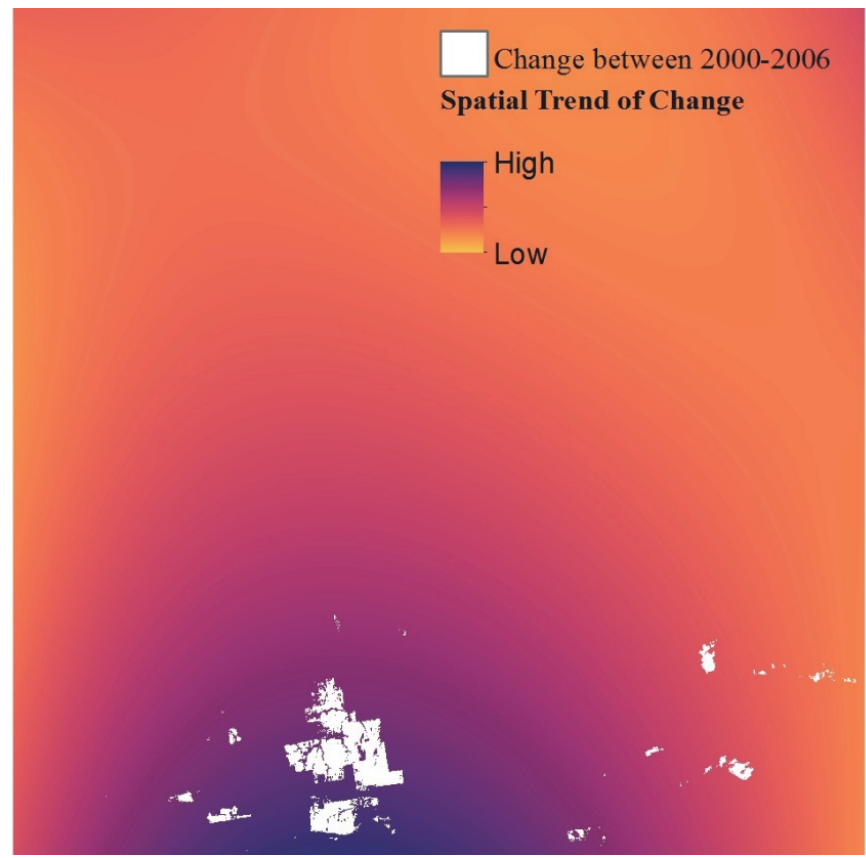

Figure 5. Spatial trend of change.

\section{Calculation of transition potentials using a MLP neural network methodology}

Transition potentials are expressed as the likelihood of one land cover category to another (Paegelow and Camacho Olmedo, 2008). In this case, only transition from forest to anthropogenic disturbance was modelled. A MLP Neural Network approach was used to create transition potential maps. Five factors were identified as major driving forces of change (see Table 1) and were assessed for correlation to deforestation.

Table 2

Explanatory variables in transition sub-model structure

\begin{tabular}{lc}
\hline \multicolumn{1}{c}{ Explanatory Variable } & Type \\
\hline Distance from roads & Dynamic \\
Distance from disturbance & Dynamic \\
Terrain (DEM) & Static \\
Distance from streams & Static \\
Slope & Static \\
\hline
\end{tabular}


LCM's Test and Selection of site and driver variable module was used to test the potential power of explanatory variables (see Table 3 ). Only variables with values higher than 0.45 (strong association with change) were kept in the sub-model structure.

Table 3

Cramer's V Test for explanatory variables

\begin{tabular}{lc}
\hline \multicolumn{1}{c}{ Explanatory Variable } & Cramer's V \\
\hline Distance from roads & 0.4730 \\
Distance from disturbance & 0.4572 \\
Terrain & 0.1114 \\
Distance from streams & 0.0493 \\
Slope & 0.0233 \\
\hline
\end{tabular}

The transition potential from forest to disturbance was modelled using the MLP neural network methodology. The LMC sub model was used to create the transition potential map (MLP achieved an accuracy rate of $94.56 \%$ and a RMS value of 0.20 ). The outcome of the model is a transition potential map for transition from forest to disturbance (see Figure 6). Each pixel on this map contains the probability value (from 0 to 1 ) of changing from forest to anthropogenic disturbance.

\section{Potential for transition from 1 to 2}

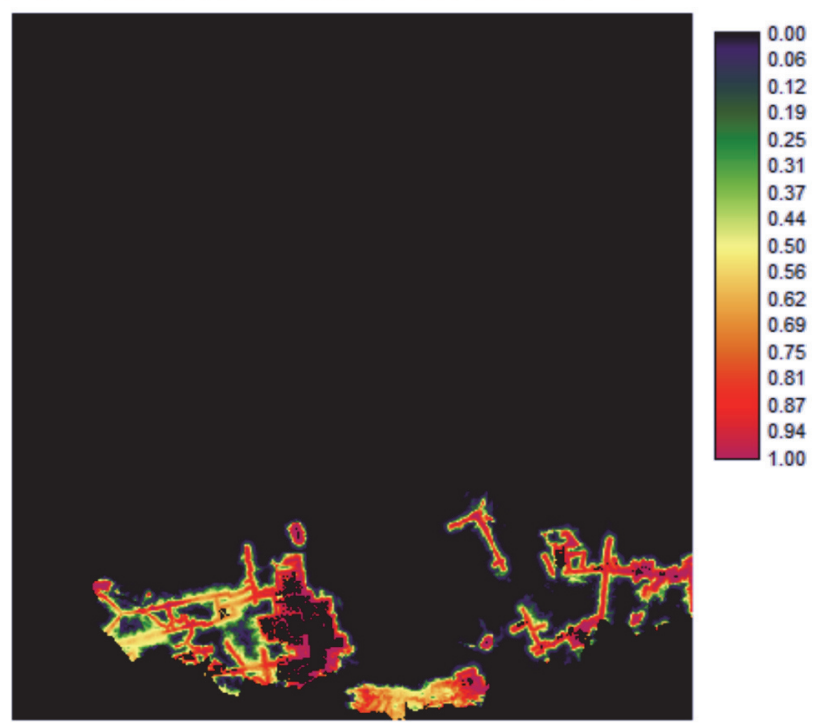

Figure 6. Transition potential from forest to anthropogenic disturbance. 


\section{Assessment of the model performance by predicting a 2009 land cover} and comparing it with an actual 2009 land cover map

Markov chain analysis was used to predict the quantity of change in 2009 and then compare to an actual 2009 land cover map. LCM provides two basic models of prediction: a hard prediction model and a soft prediction model.
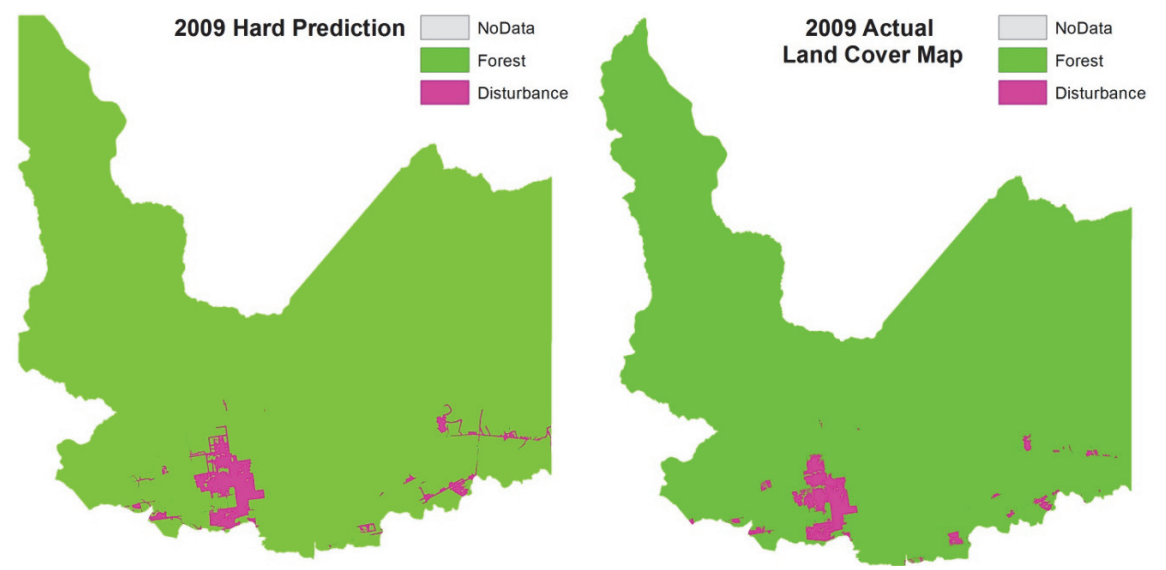

Figure 7. Hard prediction of Kayabi forest condition in 2009 and actual 2009 land cover map.

Figure 7 shows two disagreements in the prediction are either concerned with quantity or with location of change. The assessment of the hard prediction was carried out with the LCM Validate function (see the resulting map in Figure 8 and output of function in Figure 9).

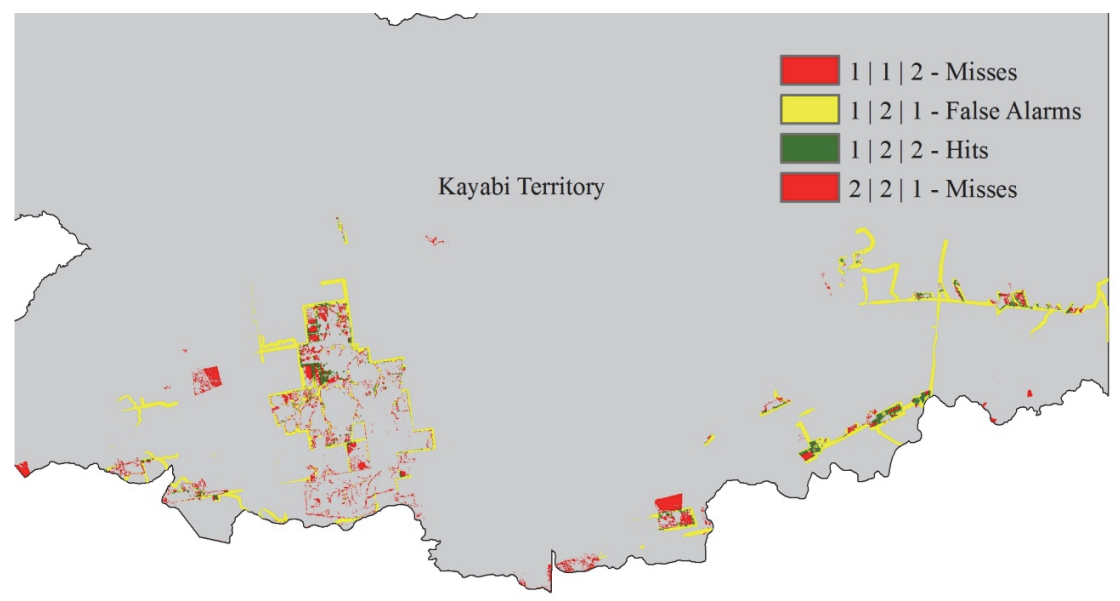

Figure 8. Validation map: hits, false alarms and misses. 


\begin{tabular}{|c|c|c|c|c|}
\hline \multirow{2}{*}{ Resolution level } & \multirow{2}{*}{\multicolumn{2}{|c|}{ MBR: $1 \times 1$}} & \multirow[b]{3}{*}{ Perfect } & Close \\
\hline & & & & \\
\hline Model Type & Random & Yours & & \\
\hline$\%$ Correct & $33.33 \%$ & $100.00 \%$ & $72.30 \%$ & 16ки. \\
\hline Improvement & $\cdots$ & $66.67 \%$ & $-27.70 \%$ & \\
\hline Kappa no: & 1.7107 & & & More $\gg>$ \\
\hline
\end{tabular}

Figure 9. Validation results.

As the hard prediction is a single realization of a future scenario chosen from many equally plausible scenarios (Eastman, 2009), it is very difficult to achieve an accurate hard prediction. The soft prediction identifies vulnerability to change, and thus provide a more meaningful map (see Figure 10).

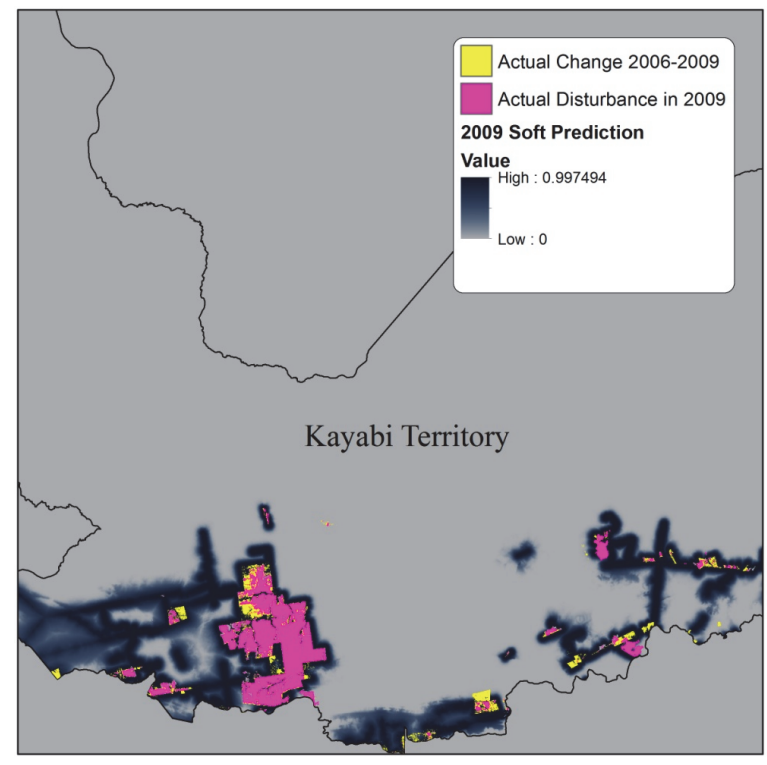

Figure 10. 2009 Soft prediction.

A quantitative assessment of the soft prediction was carried out using receiver operating characteristic (ROC) statistics. The ROC is able to compare a map of actual change to maps of modeled suitability for land-cover change (Pontius and Schneider, 2001). The result of the ROC statistic was 0.987 , which is a very strong value and indicates the soft prediction was very accurate. 


\section{Predicting the Kayabi Territory forest condition in 2020}

Both hard and soft predictions were produced for the year 2020 (see Figure 11).
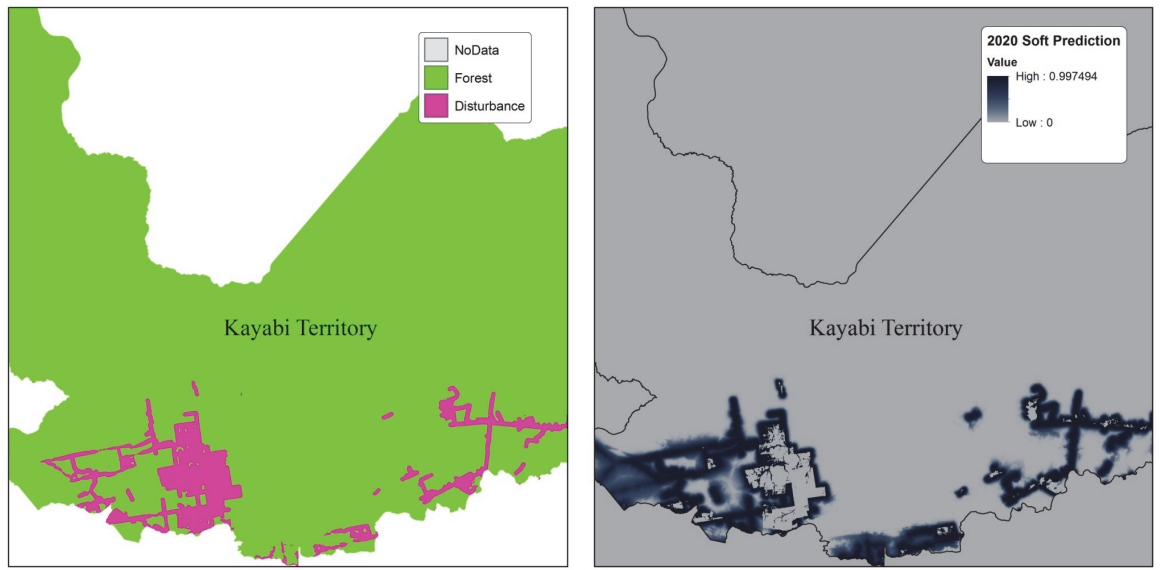

Figure 11. Map Predictions for 2020: hard prediction (left-hand side) and soft prediction (right-hand side).

\section{Discussion and conclusions}

The results of the prediction of landscape change for 2020 (see Table 4) indicate that by the year 2020, assuming the nature of forest development does not change, an additional 36,000 hectares of forest will be lost in the Kayabi Territory, making a total of 60,645 hectares for the period 2000-2020.

\section{Table 4}

Time Analysis of forest lost in Kayabi Territory

\begin{tabular}{cc}
\hline Year & Forest Lost (ha) \\
\hline 2000 & 1,776 \\
2006 & 18,018 \\
2009 & 5,040 \\
2020 & 35,811 \\
\hline Total & 60,645 \\
\hline
\end{tabular}

The predicted amount of the deforestation seems high if compared to reality. This can be explained, as the model uses the deforestation rate calculated to train the model. According to the change analysis 16,242 hectares were lost in six years (2000- 
2006), resulting an average deforestation rate of 2,707 hectares per year. External factors play an important role in interpreting the results. In this case, it is known rates of deforestation were impacted by legal injunction process. Such events are very difficult to incorporate into the model.

Figure 12 shows a time series of land cover maps of the Kayabi Territory consistent with the hypothesis that roads and previous disturbance are the main drivers for deforestation. The analysis also confirmed new disturbed areas serve as seeds for a more intense clearing activity in the future.
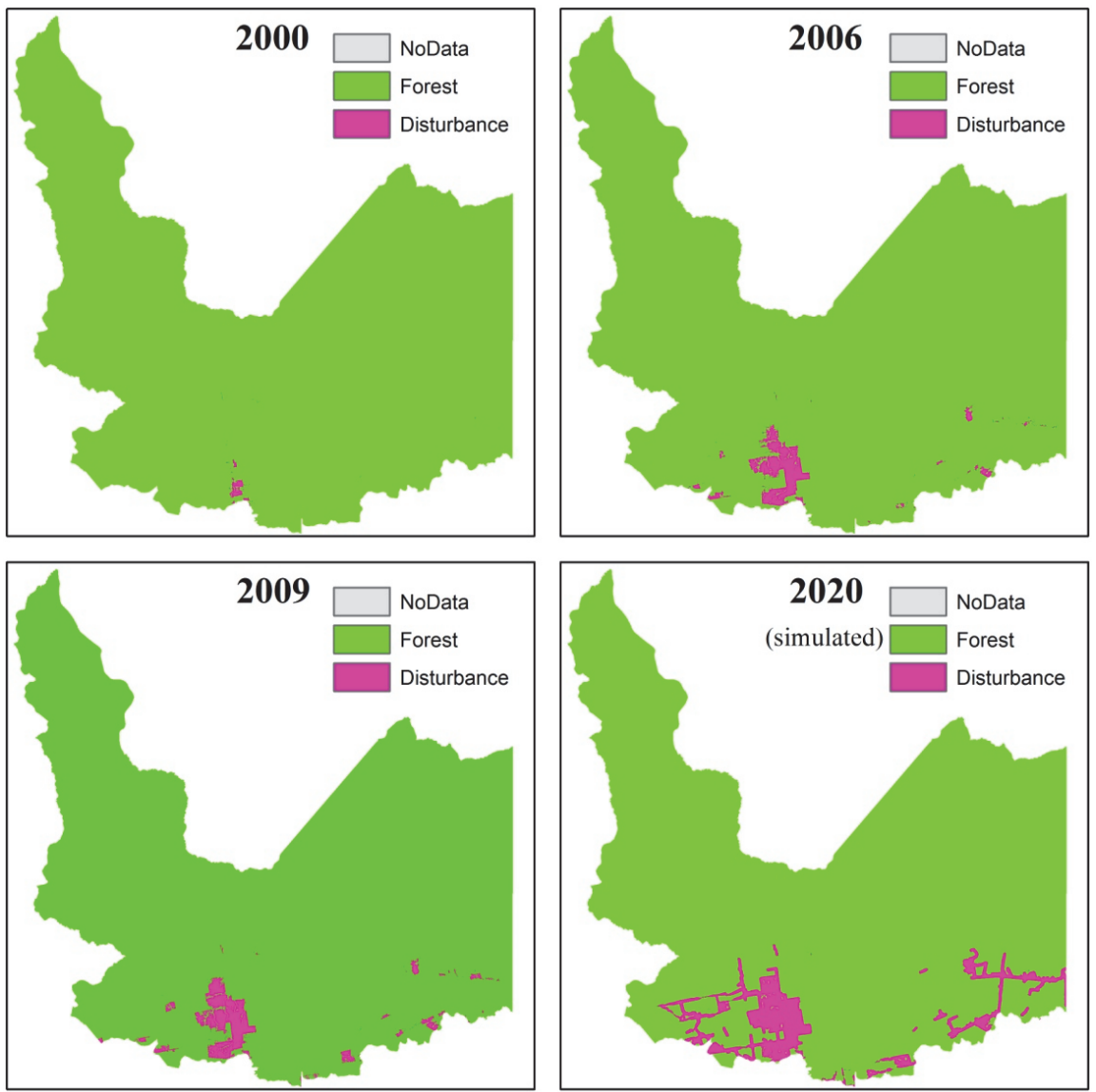

Figure 12. Time series Analysis of deforestation in Kayabi Territory.

Based on visual interpretation of the simulation and the ROC criterion, it is clear the soft predictions were produced with a satisfactory level of accuracy. Figure 13 shows the 2020 soft prediction overlaid on a 2011 Landsat image (July 25, 2011), where it is clear post 2009 disturbed areas are vulnerable. 


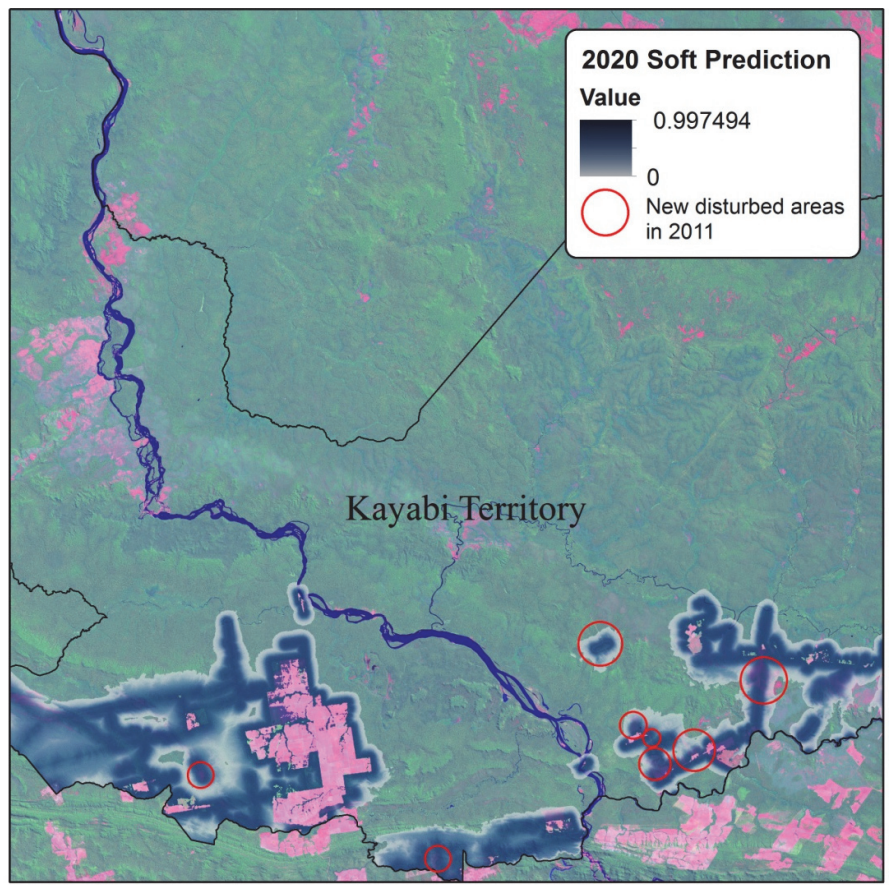

Figure 13. The 2020 soft prediction overlaid on a 2011 Landsat.

LUCC modelling is an effective mean for adequate land use planning and the development of sustainable environmental management policies. GIS, remote sensing and modelling software are ideal tools to accomplish these tasks.

This study was able to successfully simulate future deforestation expansion in the region and also, identified the main landscape attributes driving deforestation expansion in the Kayabi Territory. Distance from roads and distance from existing disturbance were found as the key factors driving deforestation. Nevertheless, other important aspects have great impact on LUCC. For instance, despite the demarcation of the Kayabi Territory intended conservation of the forest it seems that, far from its purpose of protecting it, it increased the deforestation rates because the uncertainty to the land owners of their land tenure. Single farmers were the most active actors in the deforestation process. The soft prediction maps simulated in this study provide excellent means for monitoring areas where selective logged has happened and therefore to protect new areas that are susceptible to be disturbed.

\section{References}

Ademola, K.B. and Takashi, O. (2007). "Geostatistical techniques for incorporating spatial correlation into land use change models", International Journal of Applied Earth Observation and Geoinformation, 9:438-446. 
Asner, G.P.; Broadbent, E.N.; Oliveira P.J.; Keller M., Knapp D.E. and Silva J.N. (2006). "Condition and fate of logged forests in the Brazilian Amazon", PNAS, 12947-12950.

Chang, K.-T. (2010). Introduction to Geographic Information Systems, Singapore, McGraw-Hill.

Eastman J.R. (2009). IDRISI Guide to GIS and Image Processing, Clark University, Worcester.

Fearnside, P.M. (2007). "Deforestation in Amazonia", Retrieved Agust 13, 2011, from The Encyclopedia of Earth, <http://www.eoearth.org/article/Deforestation in_Amazonia> (March 30).

R. Gil Pontius Jr. and Laura C. Schneider (2001). "Land-cover change model validation by an ROC method for the Ipswich watershed, Massachusetts, USA", Agriculture, Ecosystems \& Environment, 85(1-3), June, pp. 239-248, $<\mathrm{http}: / /$ dx.doi.org/10.1016/S0167-8809(01)00187-6>, $<\mathrm{http}: / / \mathrm{www}$. sciencedirect.com/science/article/pii/S0167880901001876>.

Laurance, W.F.; Albernaz, A.K.; Schroth, G.; Fearnside, P.M.; Bergen, S.; Veinticinque, E.M., et al. (2002). "Predictors of Deforestation in the Brazilian Amazon", Journal of Biogeography, pp. 737-748.

Paegelow M. and Camacho Olmedo M.T. (2008). Modelling Environmental Dynamics: Advances in Geomatics, Springer, Berlin.

Vitousek, P.; Mooney, H.; Lubchenco, J. and Melillo, J. (1997). "Human domination of Earth's ecosystems", Sicence, 277:494-499. 